\title{
POTENCY OF RAMIN (Gonystylus bancanus Kurtz.) AND OTHER COMMERCIAL SPECIES IN PEAT SWAMP FOREST MANAGED WITH TPTI SILVICULTURAL SYSTEM IN BAGAN, RIAU
}

\author{
Hendromono $^{1}$
}

\begin{abstract}
Ramin (Gonystylus bancanus Kurtz.) is one of the tree species in peat-swamp forest that is endangered due to excessive exploitation. The objective of this research was to assess the potency of ramin and other commercial tree species in primary and logged over peat-swamp forests at Bagan, Riau. The tree stands were inventoried in primary forest of the 2004 and 2006 Annual Work Plan (RKTs) and in the 1997 and 2001 RKTs managed with Indonesian Selective Cutting and Planting (TPTI) silvicultural system. The result showed that ramin in Bagan peat-swamp forest was not evenly distributed. The total number of ramin in tree stage in primary forests was fewer than that in logged over forests. The total number of ramin species at tree stage in primary forest was between 4.5 and 5 trees $\mathrm{ha}^{-1}$ with the important value index (IVI) of 10.3 to $12.0 \%$, whereas the one at logged over forest were between 2.5 and 15 trees ha ${ }^{-1}$ with the IVI indices of 7.9 to $20.4 \%$. Commercial species of swamp meranti (Shorea uliginosa and S. teysmaniana) and balam/suntai or (Palaquium spp.) were dominant at tree stage both in the primary and the logged over forests. Enrichment in logged over forests is not needed since the total number of seedlings and saplings is enough. The total number of potential core trees in logged over forests was enough for the next cutting cycle. The effort that must be done in logged over forests is to protect them from illegal logging.
\end{abstract}

Keywords: potency, ramin (Gonystylus bancanus Kurtz.), commercial tree species, peat-swamp forest, TPTI

\section{i. INTRODUCTION}

Tree species exploited by many people in peat-swamp forest is ramin (Gonystylus bancanus Kurtz.). Ramin wood is included as attractive wood with the price higher than meranti. The price of ramin moulding recently is between US $\$ 675$ and US $\$ 750 \mathrm{~m}^{-3}$. Therefore, many ramin trees at peat-swamp forest in Sumatera and Kalimantan were cut. Ramin potency at Teluk Umpan peat-swamp forest Central Kalimantan before exploitation was 45 trees ha $^{-1}, 10$ poles ha ${ }^{-1}, 200$ saplings ha ${ }^{-1}$ and 16,000 seedlings ha ${ }^{-1}$. One year after cutting, no tree and pole, but only 6,000 wold seedlings ha ${ }^{-1}$ were found (Daryono, 1996). This condition showed that ramin trees with the stem diameter of less than $20 \mathrm{~cm}$ were also then cut. Since ramin trees in natural forest have been scarce, the species were grouped in Appendix II following the Convention on International Trade of Endangered Species of Wild Fauna and Flora (CITES) in 2005 (Suhartono and Mardiastuti, 2002).

\footnotetext{
${ }^{1}$ Forest and Nature Conservation Research and Development Center, Bogor
} 
Ramin and other commercial trees potency in peat-swamp forest are large enough. However, the biodiversity and yearly volume increment of trees in peat-swamp forest are generally lower than those in dry land of tropical rain forest. Some trees in peat-swamp forest with stem diameter more than $50 \mathrm{~cm}$ have trunk with hole inside the wood. That is the reason why the minimum stem diameter of commercial trees which can be cut in Selective Cutting and Planting System (TPTI) at peat-swamp forest is $40 \mathrm{~cm}$. Actually, TPTI's silvicultural system is appropriate for tropical rain forest which consists of many species and various age classes, however because some forest concession right holders (Hak Pengusahaan Hutan $=\mathrm{HPH}$ ) were not obeying the rule of TPTI, the continuity of wood production was not guaranted (Direktorat Produksi Hasil Hutan, 2000). Some commercial tree species such as ramin and eboni have been scarce in the forest. The scarcity of ramin in Tangkiling and Sampit (Central Kalimantan) was reported by Sutisna et al. (1988), and in Teluk Umpan (Central Kalimantan) by Daryono (1996).

The purpose of the paper was to inform ramin and other commercial trees potency at Bagan, Riau peat-swamp forest which was managed by one HPH permited to exploit ramin trees in certain extractable amount. This research hopefully could be used for evaluation in the implementing of TP'TI system at peat-swamp forest in Riau.

\section{METHODOLOGY}

\section{A. Time and Research Location}

The research was carried out in December 2003 to October 2004 at Bagan Forest's Sub District, Dumai Forest District, under Riau Province Forest District. The study area was located between $100^{\circ} 48^{\prime}-101^{\circ} 13^{\prime} \mathrm{WL}$ and $1^{\circ} 49^{\prime}-2^{\circ} 18^{\prime} \mathrm{NL}$. The soil types were Organosol and Gley Humus. The elevation was about $0-25 \mathrm{~m}$ above sea level. Average annual rainfall was $2,637 \mathrm{~mm}$ with "A" climate type according to classification by Schmidt and Ferguson. The highest rainfall occurred between November and December, and the lowest rainfall between March and July. The study area was peaty with the depth of peat more than $2 \mathrm{~m}$. The location was inundated between 5 and $40 \mathrm{~cm}$ in wet season and not inundated in dry season.

\section{B. Method}

Inventory in 2004 and 2006's Annual Work Plan (Rencana Karya Tahunan=RKT) primary forest, and in 1997 and 2001 logged over forest was done twice in the year 2003 and 2004. Each forest area was inventoried by using two observation lines. Each observation line had the size $20 \mathrm{~m}$ x $500 \mathrm{~m}$, consisting of 25 observation plots. The distance between observation lines in a forest area was $100 \mathrm{~m}$.

Evaluation on biodiversity and natural regeneration were done by making plots with different sizes. Observation plot provided for tree stage (stem diameter more than $20 \mathrm{~cm}$ ) was $20 \mathrm{~m} \times 20 \mathrm{~m}$, pole stage (stem diameter $10-19 \mathrm{~cm}$ ) was $10 \mathrm{~m} \times 10 \mathrm{~m}$, sapling stage (stem diameter less than $10 \mathrm{~cm}$, height more than $1.5 \mathrm{~cm}$ ) was $5 \mathrm{~m} \times 5 \mathrm{~m}$ and seedling stage (height less than $1.5 \mathrm{~m}$ ) was $2 \mathrm{~m} \times 2 \mathrm{~m}$. 
Parameters measured were tree height at crown base, stem diameter at $1.3 \mathrm{~m}$ above the ground or $20 \mathrm{~cm}$ above buttres root, and total number and species of trees, poles, saplings, and seedlings in one hectare.

\section{Data Analysis}

The leaves and twigs of trees which their botanical name could not be identified were taken for determination in Bogor. The tree species were groups in their particular categories, i.e. ramin, other commercial species, and non commercial species based on 1992 Forestry Manual (Anonymous, 1992). To calculate value of density, frequency, dominancy and important value index (IVI) were determined with the formula of Curtis and Mcintosh (Soerianegara and Indrawan, 1978) was used as follow:

- Density $=$ total species $/$ total area

- Relative density $=($ density of one species $/$ density of all species $) \times 100 \%$

- Frequency $=$ total plots of one species found / total plots of all species

- Relative frequency = (frequency of one species found / frequency of all species $) \times 100 \%$

- Dominancy $=$ covered area of one species / total plot area

- Relative dominancy $=($ dominancy of one species $/$ dominancy of all species $) \times 100 \%$

- Important value index (IVI) = relative density + relative frequency + relative dominancy

For seedling and sapling stages IVI calculation was based on relative density and relative frequency.

Stand potency was calculated by summing total volume of each individual tree per hectare. Tree volume was calculated by the equation:

Tree volume $=\mathrm{n} / 4 \times(\mathrm{D} / 100)^{2} \mathrm{x} \mathrm{T} \times 0.5495 \times 1 \mathrm{~m}^{3}$

$\mathrm{D}=$ stem diameter at $1.3 \mathrm{~m}$ or $20 \mathrm{~cm}$ above buttres root

$\mathrm{T}=$ height of trunk at crown base

$0.5495=$ stem form factor

Observation and calculation data were tabulated and analysed descriptively.

\section{RESULT AND DISCUSSION}

\section{A. Species Composition and Domination}

Species composition in the research area was dominated by commercial tree species. Of the 42 species found in study area, 30 were commercial trees including ramin trees, while the other 12 were lesser known species (Appendix 1). After exploitation in 1997, three species were lost compared to the species in the 2004 RKT primary forest. However, that condition was not to be a problem because based on Matius study in Batu Ampar (1995) cited by Ernayati and Yuliaty (2004), before exploitation primary forest consisted of 108 tree species, but in the 20 years-logged over forest the number of species increased to 114 species.

Calculation result of IV index indicated that seedling stage in 2004 RKT primary forest was in succession and dominated by milas (55.2\%), balam $(31.9 \%)$ and pasir-pasir $(19.2 \%)$, sapling stage was dominated by pasir-pasir (24.6\%), arang-arang $(20.3 \%)$ and balam $(19.9 \%)$, pole and tree stages were dominated by meranti batu $(52.5 \%)$ and balam $(33.6 \%)$. 
Regeneration at seedling stage in 2006 RKT primary forest was dominated by kelat $(37.0 \%)$ and pasir-pasir (19.9\%), sapling stage by medang (21.8\%), pasir-pasir (19.7\%) and balam $(18.8 \%)$, pole stage by jambu-jambu $(91.0 \%)$ and balam $(33.7 \%)$, tree stage by jambu-jambu $(45.3 \%)$, balam (43.4\%) and meranti batu (40.8\%). Regeneration at seedling stage in 2001 logged over forest was dominated by milas $(82.2 \%)$ and timah-timah $(18.0 \%)$, sapling stage by jambu-jambu $(25.4 \%)$ and arang-arang $(17.0 \%)$, while at pole and tree stages was by suntai $(37.0 \%)$, meranti batu $(36.1 \%)$ and ramin $(22.3 \%)$. Natural regeneration at seedling stage in 1997 logged over forest was dominated by balam $(57.1 \%)$, pasir-pasir $(31.3 \%)$ and milas $(31.2 \%)$, sapling stage by pasir-pasir $(36.4 \%)$ and balam $(20.5 \%)$, while at pole and tree stages was by balam $(35.0 \%)$ and meranti batu $(34.5 \%)$.

Compared to ramin at Teluk Umpan in the peat-swamp's primary forest, Central Kalimantan (Daryono, 1996), the potency of ramin at Bagan's peat-swamp primary forest Riau was only one ninth. However, after exploitation with TPTI the total number of ramin trees at Bagan was still between 2.5 and 15 trees ha $^{-1}$ (IVI $=7.9-20.4 \%$ ) (Appendix 2), whereas at Teluk Umpan, ramin at pole and tree stages could not found anymore. This is because forest concession right holder did not know that ramin species have included in Appendix III CITES in 1996; therefore, all pole and tree stages of ramin were cut at Teluk Umpan. This selective cutting manner disobeyed TPTI regulation, which only allows to cut the trees with minimum trunk diameter of $40 \mathrm{~cm}$. Ramin exploitation at Bagan forest applied TPTI and CITES regulations, by leaving several ramin trees as potential core and mother trees.

The total number of ramin trees in the 2001 logged over forest (16 km from logpond) was 15 trees ha ${ }^{-1}$, whereas in the 1997 logged over forest ( $6.5 \mathrm{~km}$ from logpond) was only 2.5 trees $\mathrm{ha}^{-1}$. There was a tendency that the closer the distance to the coast, the fewer the number of ramin trees, possibly because of increasing thickness of peat. This opinion was supported by Istomo's observation result conducted on the same area (personal comm in 2003).

The number of natural regeneration seedlings per hectare in primary and secondary forest was a lot. In the first inventory (2003) the number of seedlings ha ${ }^{-1}$ in primary forest was 28,350 , larger than those in the 1997 logged over forest (20,500 seedlings). But in the second inventory (2004), the number of seedlings in primary forest were fewer than those in the 1997 logged over forest (Table 1). It was because in logged over forest, part of the area opened up, therefore, more sun light especially red light spectrum could reach co-dominant trees which can induce flowering process (Salisbury and Ross, 1992). In logged over forest, light intensity reaching ground was larger thereby enabling to stimulate germination of seeds on the ground. The more sunray reach the ground, the better the stimulation of wild seedlings to grow faster, consequently the total number of saplings in logged over forest was larger than those in primary forest (Table 1). The number of ramin seedlings in primary forest was between 0.8 and $2.5 \%$ of the total number of seedlings, whereas in sapling stage was between 1.9 to $2.5 \%$ of the total number of saplings. The existence of ramin seedlings at Bagan's peatswamp forest was much less than those of seedlings at Teluk Umpan peat-swamp forest which have ramin seedlings $16,000 \mathrm{ha}^{-1}$ or $69.6 \%$ of the total seedlings. Total number of ramin saplings at Teluk Umpan were $200 \mathrm{ha}^{-1}$ or $7.5 \%$ of total saplings (Daryono, 1996).

The total number of wild seedlings at ex-railway track was not enough (10,275 seedlings), and most of them were pioneer species e.g. Macaranga spp, Eugenia spp. and Ilex macrophylla Hook f. seedlings of commercial species which were cut in selective cutting system 
such as ramin, durian burung, balam and suntai were not found at this area except meranti batu (Table 1). Therefore, ex-railway track should be rehabilitated by planting semi tolerant seedling species (ramin, balam or suntai).

Because only small light intensity from sunray reached the ground, many wild seedlings were dead in primary forest, consequently the total number of saplings was fewer than that in logged over forest. Considering that the total number of natural seedlings and saplings in the 1997 and 2001 logged over forests was enough, it was not necessary to enrich these areas by planting. Rehabilitation can be done at ex-landing construction, ex-railway track and ex-skidtrail construction. The species that should be planted were the ones which had been exploited. Open area could be planted with intolerant species, whereas medium shading area could be with semi-tolerant species.

Table 1. Number of seedlings and saplings in primary forest of the 2004's RKT and the 2006's RK'T, logged over area of 1997, and ex-railway track

\begin{tabular}{|c|c|c|c|c|c|}
\hline \multirow[b]{2}{*}{ No. } & \multirow[b]{2}{*}{ Forest Area } & \multicolumn{4}{|c|}{ Number hectare ${ }^{4}$} \\
\hline & & $\begin{array}{r}\text { Seedling } \\
\text { of } 2003\end{array}$ & $\begin{array}{l}\text { Seedling } \\
\text { of } 2004\end{array}$ & $\begin{array}{l}\text { Sapling } \\
\text { of } 2003\end{array}$ & $\begin{array}{l}\text { Sapling } \\
\text { of } 2004\end{array}$ \\
\hline 1. & $\begin{array}{l}\text { Primary forest of the } 2004 \\
\text { RKT } \\
\text { Ramin }\end{array}$ & $\begin{array}{c}28,350 \\
50\end{array}$ & $\begin{array}{r}35,950 \\
300\end{array}$ & $\begin{array}{r}2,856 \\
56 \\
\end{array}$ & $\begin{array}{r}2,752 \\
64\end{array}$ \\
\hline 2. & $\begin{array}{l}\text { Primary forest of the } 2006 \\
\text { RKT } \\
\text { Ramin }\end{array}$ & $*$ & $\begin{array}{r}33,550 \\
850\end{array}$ & * & $\begin{array}{c}3,296 \\
64\end{array}$ \\
\hline 3. & $\begin{array}{l}1997 \text { Logged over forest } \\
\text { Ramin }\end{array}$ & $\begin{array}{c}20,500 \\
450 \\
\end{array}$ & $\begin{array}{c}37,100 \\
800\end{array}$ & $\begin{array}{c}3,432 \\
32 \\
\end{array}$ & $\begin{array}{c}3,494 \\
32 \\
\end{array}$ \\
\hline 4. & $\begin{array}{l}2001 \text { Logged over forest } \\
\text { Ramin }\end{array}$ & $\begin{array}{c}12,200 \\
50\end{array}$ & ** & $\begin{array}{c}3,752 \\
16 \\
\end{array}$ & $\begin{array}{l}* * \\
* *\end{array}$ \\
\hline 5. & $\begin{array}{l}\text { Ex-railway track } \\
\text { Ramin }\end{array}$ & - & $\begin{array}{c}10,275 \\
0\end{array}$ & - & * \\
\hline
\end{tabular}

\footnotetext{
Notes: $\quad-\quad=$ railway track exist, not inventoried;

* = railway track was not existed yet, not inventoried

$* *$ = railway track had been disclosed, not inventoried
}

\section{B. Wood Potency}

The inventory result showed that the total number of trees with stem diameter ranging between 20 and $39 \mathrm{~cm}$ and those with stem diameter more than $40 \mathrm{~cm}$ in the 1997 logged over forest were fewer than that in the 2001 logged over forest. It maybe because the exploitation in 1997 was more intensive than that in 2001, since the location of the 1997's secondary forest ( $6.5 \mathrm{~km}$ from log-pond) was nearer than that of the 2001 's secondary forest (16 km from log-pond), so the cost of wood transportation was cheaper. In location far away from log-pond, only tree species with high value wood were cut to compensate the cost of transportation.

The wood potency of commercial species in the 2004 RKT on primary forest with stem diameter greater than $40 \mathrm{~cm}$ was more than $140 \mathrm{~m}^{3} \mathrm{ha}^{-1}$ and in fact larger than that in the 2006 RKT primary forest (Table 2), because several meranti batu with stem diameter of larger than 
$100 \mathrm{~cm}$ were found in the $2004 \mathrm{RKT}$ primary forest. Based on this forest condition, tree volume exploited and extracted by TPTI system in the 2006 RKT on primary forest should be less than that in the $2004 \mathrm{RKT}$ on primary forest. Meranti batu trees revealed their dominance in primary and secondary forests in Bagan Sub District. It was recommended that meranti batu with stem diameter of more than $100 \mathrm{~cm}$ should be prioritized to be cut to give opportunity for co-dominant trees to grow faster.

The potency of the 2001 and 1997 logged over forest was enough for the next cutting cycle. The total number of potential core trees in the 2001 and 1997 logged over forest was far greater than that in the TPTI regulation $\left(25\right.$ trees $\left.\mathrm{ha}^{-1}\right)$. Measurement on average trunk diameter increment of commercial trees annually was $0.55 \mathrm{~cm}$, it means that logged over forest could produce wood volume at least similar to that of the first cutting. Moreover, if potential core trees were added with trees of more than $40 \mathrm{~cm}$ stem diameter, the wood production for the next cutting cycle may be larger. The important thing may be done is that the logged over forest must be protected from illegal logging.

Table 2. Total number of trees and stand volume $\mathrm{ha}^{-1}$ in the $2004 \mathrm{RKT}$ and $2006 \mathrm{RKT}$ on primary forests, and the 1997 and 2001 logged over forests

\begin{tabular}{|c|c|c|c|c|c|}
\hline \multirow[b]{2}{*}{ No. } & \multirow[b]{2}{*}{ Forest condition } & \multicolumn{2}{|c|}{ Diameter $(20-39 \mathrm{~cm})$} & \multicolumn{2}{|c|}{ Diameter $>40 \mathrm{~cm}$} \\
\hline & & $\begin{array}{c}\text { Total number } \\
\text { (tree/ha) }\end{array}$ & $\begin{array}{l}\text { Volume } \\
\left(\mathrm{m}^{3} / \mathrm{ha}\right)\end{array}$ & $\begin{array}{l}\text { Total number } \\
\text { (tree/ha) }\end{array}$ & $\begin{array}{l}\text { Volume } \\
\left(\mathrm{m}^{3} / \mathrm{ha}\right)\end{array}$ \\
\hline 1. & $\begin{array}{l}\text { 2004RKT primary forest } \\
\text { a. Ramin } \\
\text { b. Other commercials } \\
\text { c. Others }\end{array}$ & $\begin{array}{r}2.5 \\
68.5 \\
23.5 \\
\end{array}$ & $\begin{array}{r}2.56 \\
43.08 \\
11.57 \\
\end{array}$ & $\begin{array}{r}2.5 \\
36.5 \\
8.0 \\
\end{array}$ & $\begin{array}{r}6.45 \\
136.55 \\
12.04 \\
\end{array}$ \\
\hline 2. & $\begin{array}{l}2006 \text { RKT primary forest } \\
\text { a. Ramin } \\
\text { b. Other commercials } \\
\text { c. Others }\end{array}$ & $\begin{array}{r}2.5 \\
105.0 \\
20.0 \\
\end{array}$ & $\begin{array}{r}1.69 \\
46.56 \\
7.03 \\
\end{array}$ & $\begin{array}{r}2.0 \\
30.0 \\
6.0 \\
\end{array}$ & $\begin{array}{r}6.57 \\
53.36 \\
5.82 \\
\end{array}$ \\
\hline 3. & $\begin{array}{l}1997 \text { Logged over forest } \\
\text { a. Ramin } \\
\text { b. Other commercials } \\
\text { c. Others }\end{array}$ & $\begin{array}{r}0.5 \\
72.0 \\
18.0 \\
\end{array}$ & $\begin{array}{r}0.46 \\
39.96 \\
9.45\end{array}$ & $\begin{array}{r}2.0 \\
22.5 \\
8.5 \\
\end{array}$ & $\begin{array}{r}4.54 \\
58.31 \\
19.56 \\
\end{array}$ \\
\hline 4. & $\begin{array}{l}2001 \text { Logged over forest } \\
\text { a. Ramin } \\
\text { b. Other commercials } \\
\text { c. Others }\end{array}$ & $\begin{array}{l}12.5 \\
82.5 \\
15.5 \\
\end{array}$ & $\begin{array}{r}12.05 \\
50.31 \\
8.26 \\
\end{array}$ & $\begin{array}{r}2.5 \\
25.0 \\
1.0 \\
\end{array}$ & $\begin{array}{r}7.40 \\
71.00 \\
2.35 \\
\end{array}$ \\
\hline
\end{tabular}

Ramin species with stem diameter of more than $20 \mathrm{~cm}$ in primary forest was only between 4.5 and 5 trees ha $^{-1}$, whereas that in the 2001 logged over forest was 15 trees ha ${ }^{-1}$, but in the 1997 logged over forest was 2.5 trees ha $^{-1}$ (Table 2). This condition showed that ramin trees in Bagan peat-swamp forest was not evenly distributed. Rehabilitation of ex-railway track and ex-skid-trail construction with ramin seedlings could enrich forest for the third rotation. Ramin seedlings are not suitable for rehabilitation in open area such as ex-landing construction. Observation in Bagan forest showed that ramin seedlings planted on open area had not grown shoots for 10 months. Generally, the growth of ramin in juvenile stage is slow. Measurement of ramin plantation at 5 years old on ex-landing construction area in Teluk Umpan, Central Kalimantan showed that the height and stem diameter increment were 20.01 $\mathrm{cm}_{\text {year }}{ }^{-1}$ and 0:27 $\mathrm{cm}^{-1}$ year $^{-1}$, respectively (Daryono, 1996). 


\section{CONCLUSIONS AND RECOMMENDATIONS}

\section{A. Conclusions}

1. The total number of ramin trees in Bagan peat-swamp forest, Riau varied and had a tendency that the farther the distance to the coast, the less the number of ramin trees. Total number of ramin trees in primary forest was between 4.5 and 5 trees ha $^{-1}$ (IVI $=10.3$ $-12.0 \%$ ), whereas that in logged over forest was between 2.5 and 15 trees ha $^{-1}$ (IVI $=7.9$ $20.4 \%)$.

2. Ramin was one of the dominant tree species in the 2001 logged over forest, whereas swamp meranti (Shorea uliginosa and S. teysmaniana) and balam/suntai (Palaquium spp.) trees were dominant in the primary and secondary Bagan peat-swamp forests.

3. Commercial tree volumes which can be exploited using the TPTI system at Bagan for the 2006 RKT were less than those for the 2004 RKT.

4. The total number of potential core trees afforded by commercial species in logged over forest was more than enough for the next cutting cycle, as long as the forests can be protected from illegal logging.

5. The total number of seedlings and saplings in logged over forest were enough, so it was not necessary to enrich this area. Rehabilitation is needed at ex-landing construction, exrailway track and ex-skid-trail construction areas by planting commercial tree seedlings.

\section{B. Recommendations}

1. Seedlings for rehabilitation should be with commercial species which had been exploited. Ramin and balam/suntai seedlings can be planted under medium intensity tree shade, whereas meranti batu and durian burung can be planted on ex-landing construction area.

2. It is needed to leave several ramin species as potential core or mother trees in logged over forest, because this species had been scarce at Bagan's peat-swamp forest and included in Appendix II, CITES recently.

\section{REFERENCES}

Anonim. 1992. Manual Kehutanan. Departemen Kehutanan. Jakarta.

Daryono, H. 1996. Kondisi tegakan tinggal dan permudaan alam hutan rawa-gambut setelah pembalakan dan teknik propagasinya. In "Diskusi Hasil Penelitian dalam Menunjang Pemanfaatan Hutan yang Lestari". Hal: 9-31. Pusat Penelitian dan Pengembangan Hutan dan Konservasi Alam. Bogor.

Direktorat Produksi Hasil Hutan. 2000. Peninjauan sistem silvikultur pada areal pengusahaan hutan alam produksi. Paper presented on Lokakarya Pembahasan Sistem Silvikultur sesuai karakteristik Unit KPHP dalam rangka Strategi Pengelolaan Hutan Alam Produksi. 25 Januari. Direktorat Jenderal Pengelolaan Hutan Produksi. Jakarta. 
Ernayati and N. Yuliaty. 2004. Keragaman jenis semai pasca pembalakan dengan sistem konvensional dan RIL (Reduce Impact Logging) di PT. Inhutani I. Labanan. Buletin Poltanesa 4(1): 54-64. Politeknik Pertanian Negeri Samarinda, Kalimantan Timur.

Salisbury, F.B. and C.W. Ross. 1992. Plant Physiology. Wadsword Publishing Co., Belmont.

Soerianegara, I. and A. Indrawan. 1978. Ekologi Hutan Indonesia. Departemen Manajemen Hutan, Fakultas Kehutanan, IPB. Bogor.

Suhartono, T. and A. Mardiastuti. 2002. CITES Implementation in Indonesia. Nagao Natural Environment Foundation.

Sutisna, U., H.C. Soeyatman, and M. Wardani. 1988. Analisis komposisi jenis pohon hutan rawa gambut Tangkiling dan Sampit, Kalimantan Tengah. Buletin Penelitian Hutan. No. 497: 41-56. Pusat Penelitian dan Pengembangan Hutan. Bogor. 
Appendix 1. List of tree species in Bagan's peat-swamp forest, Riau

\begin{tabular}{|c|c|c|c|}
\hline No. & Local name & Family & Botanic name \\
\hline 1. & Arang-arang* & Ebenaceae & Diospyros spp. \\
\hline 2. & Asam-asam* & Sapotaceae & Palaquium ridleyi King \& Gamble. \\
\hline 3. & Balam* & Sapotaceae & Palaquium spp. \\
\hline 4. & Bintangur* & Guttiferae & Calophyllum soulattri Burm. \\
\hline 5. & Cabe-cabe & Celastraceae & Bhesa robusta (Roxb.) Ding Hou \\
\hline 6. & Darah-darah* & Myristicaceae & Myristica viliosa Warb. \\
\hline 7. & Durian burung* & Bombacaceae & Durio carinatus Mast. \\
\hline 8. & Geronggang* & Hypericeae & Cratoxylon arborescens $\mathrm{Bl}$ \\
\hline 9. & Huni & Euphorbiaceae & Antidesma bunins $\quad$ (L.) Spring \\
\hline 10. & Jangkang & Annonaceae & Xylopia spp. \\
\hline 11. & Jambu-jambu* & Myrtaceae & Eugenia spp. \\
\hline 12. & Kelat* & Myrtaceae & Eugenia spp. \\
\hline 13. & Kempas* & Caesalpiniaceae & Koompassia malaccensis Maing. \\
\hline 14. & Kenari & Burseraceae & Dacyodes spp. \\
\hline 15. & Keranji* & Leguminosae & Dialium indium $\mathrm{L}$. \\
\hline 16. & Kopi-kopi & Euphorbiaceae & Chaetocarpus castanocarpus Roxb.Thw \\
\hline 17. & Laban* & Verbenaceae & Vitex spp. \\
\hline 18. & Mahang* & Euphorbiaceae & Macaranga spp. \\
\hline 19. & Malam-malam* & Myrtaceae & Eugenia spp. \\
\hline 20. & Mangga* & Anacardiaceae & Mangifera spp. \\
\hline 21. & Manggis & Guttiferae & Garcinia celebica $\mathrm{L}$. \\
\hline 22. & Medang* & Lauraceae & Litsea spp. \\
\hline 23. & Mengkal udang & Lauraceae & Alseodaphne. spp. \\
\hline 24. & Meranti batu* & Dipterocarpaceae & Shorea uliginosa \\
\hline 25. & Meranti bunga* & Dipterocarpaceae & Shorea teysmaniana Dyer. \\
\hline 26. & Milas & Melastomataceae & Memecylon crassifolium Bakh. \\
\hline 27. & Nangka-nangka & Moraceae & Artocarpus teysmanii Miq. \\
\hline 28. & Nyatoh* & Sapotaceae & Palaquium spp. \\
\hline 29. & Pala hutan & Myristicaceae & Myristica spp. \\
\hline 30. & Parak linggau & Meliaceae & Aglaia ignea Valeton ex K. Heyne \\
\hline 31. & Pasir-pasir & Icacinaceae & Urandra scarpiodes \\
\hline 32. & Pauh & Anacardiaceae & Campnosperma spp. \\
\hline 33. & Pisang-pisang & Rhizophoraceae & Kandelia condell Droce \\
\hline 34. & Pulai* & Apocynaceae & Alstonia pneumatophora Back \\
\hline 35. & Punak* & Theaceae & Tetrameristra glabra Miq. \\
\hline 36. & Ramin* & Thymeliaceae & Gonystylus bancanus Kurtz. \\
\hline 37. & Simpur* & Dilleniaceae & Dillenia spp. \\
\hline 38. & Slumar & Boraginaceae & Cordia suchadata Lamb \\
\hline 39. & Suntai* & Sapotaceae & Palaquium spp. \\
\hline 40. & Terentang* & Anacardiaceae & Campnosperma curiculata Hlef. \\
\hline 41. & Terpis* & Annonaceae & Polyalthia bypoleuca Hook $\mathrm{f}$. \\
\hline 42. & imah & Aquifoliceae & crophylla Hook f. \\
\hline
\end{tabular}

Note: * commercial species (Anonim, 1992) 
Appendix 2. Number of species and important value index (\%) per hectare for ramin (a) and other commercial species (b, c, d, and e) in Bagan's peat-swamp forest, Riau

\begin{tabular}{|c|c|c|c|c|c|c|c|c|c|}
\hline \multirow{2}{*}{ No. } & \multirow{2}{*}{ Forest } & \multicolumn{2}{|c|}{ Seedling } & \multicolumn{2}{|c|}{ Sapling } & \multicolumn{2}{|c|}{ Pole } & \multicolumn{2}{|c|}{ Tree } \\
\hline & & $\mathbf{N}$ & IVI & $\mathrm{N}$ & IVI & $\mathrm{N}$ & IVI & $\mathrm{N}$ & IVI \\
\hline 1. & $\begin{array}{l}\text { 2004's RKT forest } \\
\text { a.ramin } \\
\text { b. meranti rawa } \\
\text { c. durian burung } \\
\text { d. balam/suntai } \\
\text { e. other commercials }\end{array}$ & $\begin{array}{r}300 \\
1,450 \\
0 \\
5,350 \\
17,050\end{array}$ & $\begin{array}{r}3.3 \\
11.0 \\
0.0 \\
10.4 \\
104.1\end{array}$ & $\begin{array}{r}64 \\
72 \\
0 \\
272 \\
1,288\end{array}$ & $\begin{array}{r}5.5 \\
6.2 \\
0.0 \\
17.9 \\
80.1\end{array}$ & $\begin{array}{r}0.5 \\
2.0 \\
0.5 \\
1.5 \\
10.5\end{array}$ & $\begin{array}{r}6.0 \\
30.4 \\
6.2 \\
21.3 \\
122.3\end{array}$ & $\begin{array}{r}5.0 \\
25.0 \\
2.0 \\
19.5 \\
67.5\end{array}$ & $\begin{array}{r}1.3 \\
35.4 \\
6.7 \\
33.1 \\
162.9\end{array}$ \\
\hline 2. & $\begin{array}{l}2006 \text { 's RKT forest } \\
\text { a. ramin } \\
\text { b. meranti rawa } \\
\text { c. durian burung } \\
\text { d. balam/suntai } \\
\text { e. other commercials }\end{array}$ & $\begin{array}{r}850 \\
2,300 \\
50 \\
1,500 \\
17,450\end{array}$ & $\begin{array}{r}5.3 \\
14.4 \\
0.6 \\
8.1 \\
101.0\end{array}$ & $\begin{array}{r}64 \\
144 \\
8 \\
392 \\
1,488\end{array}$ & $\begin{array}{r}4.6 \\
10.5 \\
0.6 \\
18.3 \\
93.5\end{array}$ & $\begin{array}{r}2.0 \\
4.0 \\
0.5 \\
6.0 \\
32.5\end{array}$ & $\begin{array}{r}11.5 \\
23.3 \\
2.9 \\
33.7 \\
178.5\end{array}$ & $\begin{array}{r}4.5 \\
26.0 \\
3.0 \\
26.5 \\
79.5\end{array}$ & $\begin{array}{r}12.0 \\
56.4 \\
5.2 \\
43.4 \\
133.5\end{array}$ \\
\hline 3. & $\begin{array}{l}1997 \text { 's logged over forest } \\
\text { a. ramin } \\
\text { b. meranti rawa } \\
\text { c. durian burung } \\
\text { d. balam/suntai } \\
\text { e. other commercials }\end{array}$ & $\begin{array}{r}800 \\
2,600 \\
50 \\
7,450 \\
16,550\end{array}$ & $\begin{array}{r}6.1 \\
17.9 \\
0.6 \\
33.4 \\
76.1\end{array}$ & $\begin{array}{r}32 \\
288 \\
8 \\
358 \\
1,128\end{array}$ & $\begin{array}{r}2.6 \\
15.1 \\
0.7 \\
20.4 \\
67.5\end{array}$ & $\begin{array}{r}0.5 \\
0.0 \\
0.0 \\
2.0 \\
15.5\end{array}$ & $\begin{array}{r}17.3 \\
0.0 \\
0.0 \\
22.0 \\
150.1\end{array}$ & $\begin{array}{r}2.5 \\
22.5 \\
1.0 \\
20.0 \\
51.0\end{array}$ & $\begin{array}{r}7.9 \\
56.0 \\
2.8 \\
20.1 \\
138.6\end{array}$ \\
\hline 4. & $\begin{array}{l}\text { 2001's logged over forest } \\
\text { a. ramin } \\
\text { b. meranti rawa } \\
\text { c. durian burung } \\
\text { d. balam/suntai } \\
\text { e. other commercials }\end{array}$ & $\begin{array}{r}50 \\
100 \\
0 \\
50 \\
4,700\end{array}$ & $\begin{array}{r}1.7 \\
2.1 \\
0.0 \\
1.7 \\
96.0\end{array}$ & $\begin{array}{r}16 \\
144 \\
0,0 \\
120 \\
1,240\end{array}$ & $\begin{array}{r}1.2 \\
9.1 \\
0.0 \\
8.1 \\
123.4\end{array}$ & $\begin{array}{r}0.0 \\
0.0 \\
0.0 \\
0.0 \\
36.0\end{array}$ & $\begin{array}{r}0.0 \\
0.0 \\
0.0 \\
0.0 \\
48.8\end{array}$ & $\begin{array}{r}15.0 \\
25.0 \\
0.0 \\
22.5 \\
60.0\end{array}$ & $\begin{array}{r}20.4 \\
33.9 \\
0.0 \\
30.5 \\
81.4\end{array}$ \\
\hline
\end{tabular}

; Notes: $\quad$ RKT $=$ Annual Work Plan

$\mathrm{N}=$ Number of species

IVI = Important Value Index $(\%)$ 